\title{
MENEROPONG KERUKUNAN SOSIAL UMAT BERAGAMA DI PERMUKIMAN TRANSMIGRASI DESA KARAVE
}

\section{SOCIAL HARMONY OF THE RELIGIOUS COMMUNITYS IN TRANSMIGRATION SETTLEMENT KARAVE VILLAGE}

\author{
Muh. Ilham Usman \\ STAIN Majene \\ Jl. Passarang Belakang BLK Majene \\ Ilhamusman1983@gmail.com \\ Naskah diterima tanggal 3 Agustus 2019, Naskah direvisi tanggal 29 Agustus 2019, Naskah disetujui tanggal 8 Oktober 2019

\begin{abstract}
Abstrak
Tulisan ini menyajikan hasil penelitian tentang kerukunan sosial umat beragama di permukiman transmigrasi desa Karave Kabupaten Mamuju Utara. Penelitian ini menggunakan metode kualitatif deskriptif untuk meneropong atau memotret kerukunan sosial umat beragama di permukiman transmigrasi desa Karave. Pengumpulan data dilakukan selama lebih 14 hari di bulan Maret 2014. Hasil penelitian menemukan bahwa kerukunan sosial umat beragama bertahan hingga hari ini, disebabkan oleh adanya faktor pendukung tercipta dan terbangunnya kerukunan sosial, diantaranya: 1). Kesadaran akan kebinekaan. 2). Melakukan perlombaan dan pertandingan agustusan serta kegiatan positif lainnya dalam rangka mempererat jalinan silaturahmi. (3). Memperkukuh jejaring sosial dalam kelompok tani sawit.
\end{abstract}

Kata Kunci: Kerukunan, Sosial, Umat Beragama, Pluralisme.

\begin{abstract}
This written provided the result of research about social harmony of the religious communitys in transmigration settlement Karave village, North Mamuju Regency. This research uses descriptive qualitative method to support for describe the social harmony of religious communitys in transmigration settlement Karave village. Data collection was carried out for more than 14 days on March 2014. The result of research found out that the social harmony of the religious communitys is still holding until now, because of some factors of supportes and harmon builders suach as: 1). Awarness of diversity; 2). Do competitions and august matches and other positive activities in order to strengthen the relationship of friendship; 3). Strengthen social networking in oil palm farmer groups.
\end{abstract}

Keyword: Harmony, Social, Religious Community, Pluralism.

\section{PENDAHULUAN}

$\mathrm{N}$ egara Indonesia sebagai negara yang mempunyai etnis, ras, agama dan suku majemuk memberikan warna tersendiri di dalam perbincangan wacana keagamaan. Dengan etnis dan ras yang beragam akan terlihat indah, jika keragaman itu dirajut dengan kedamaian dan kasih sayang, tetapi di satu sisi, jika kepuspa- ragaman itu dilandasi dengan intrik, kesalingcurigaan antara satu individu dengan individu yang lainnya, antara komunitas yang satu dengan komunitas lainnya, maka akan menjadi momok yang menakutkan bagi masyarakat Indonesia. Oleh karena itu, manusia sebagai makhluk sosial pasti memerlukan kerja sama demi keselamatan bersama dan keberhasilan mengembangkan kehidupan selanjutnya (Darwis, 2007). 
Dalam Al-Qur'an dan hadis Rasulullah Saw banyak ditemukan dalil-dalil berkaitan kerjasama, kemajemukan sebagai sunnatullah, toleransi sebagai fundamen utama ajaran Islam dan larangan intoleransi (Misrawi, 2009).

Dalam sebuah masyarakat majemuk seperti Indonesia, mozaik keragaman merupakan realita. Seluruh bangunan kebangsaan dan kehidupan masyarakat dibangun di atas landasan adanya perbedaan antarkelompok masyarakat. Persoalannya adalah bagaimana mengelola perbedaan tersebut menjadi kekuatan bagi terbentuknya masyarakat yang harmonis. Peran pemerintah tidaklah boleh dinafikan dalam mengeluarkan kebijakan-kebijakan yang mengukuhkan keragaman tersebut, tetapi menjadi ironis, jika pemerintah menyediakan lahan luas bagi tercetusnya konflik sosial.

Suka akan menuai duka, jika komunitas multi-agama, multi-etnis, multisuku tidak dirawat dengan baik. Merawat komunitas beda suku, agama dan etnis agar tidak terjadi konflik atau gesekan sosial merupakan hal yang urgen, karena pemicu dan pemacu gesekan sosial di dalam masyarakat, dipengaruhi oleh banyak faktor, seperti faktor ekonomi, faktor politik, maupun faktor agama.

Hal yang sangat ironis adalah terjadinya konflik antara satu komunitas dan komunitas lainnya bersumber dari agama. Apakah agama mengajarkan konflik antara satu komunitas dengan komunitas lainnya? Ataukah ada yang salah bagi para penganut agama menafsirkan agamanya sehingga terjadi konflik dan gesekan sosial? Menurut data SETARA Institute, sepanjang tahun 2012 telah terjadi 264 peristiwa dan 371 tindakan pelanggaran intoleran atas kebebasan beragama/berkeyakinan sebagai hak konstitusional (Halili, 2012). Pelanggaran ini meningkat dibanding tahun-tahun sebelumnya, pada tahun 2011 tercatat 244 peristiwa dan 299 bentuk tindakan pelanggaran intoleran (Hasani, 2012). Sedangkan pada tahun 2010 tercatat 216 peristiwa dan 286 tindakan intoleran (Naipospos, 2011). Dengan data yang telah terpaparkan, peristiwa dan tindakan intoleran atas kebebasan beragama/berkeyakinan dari tahun ke tahun sangat meningkat.

310 | Jurnal “Al-Qalam” Volume 25 Nomor 2 Desember 2019
Kehidupan keagamaan masyarakat desa Karave memiliki toleransi beragama yang sangat tinggi yang terdiri dari Agama Islam, Agama Kristen-Protestan, Agama KristenKatolik, dan Hindu. Keempat agama yang besar ini hidup berdampingan secara damai dengan jiwa gotong-royong dan baik. Oleh karena itu, tidaklah berlebihan bila penelitian tentang model landasan sosial antar umat beragama dalam memelihara ketahanan dan ketertiban masyarakat terpencil ini sangat urgen untuk dilakukan. Dengan beragamnya corak kehidupan beragama di desa ini, maka dapatlah ditemukan manfaat penelitian berkaitan dengan kerukunan sosial umat beragama di permukiman Karave menjadi sangat diperlukan untuk mengetahui model interaksi sosial apa saja yang membuat konflik agama, etnis dan sosial tidak meletup di daerah tersebut.

Adapun rumusan masalah pada penelitian yakni bagaimana kerukunan sosial umat beragama di permukiman desa Karave? Faktor apa saja yang membuat kerukunan sosial umat beraga di permukiman desa Karave bertahan hingga hari ini?

\section{Tinjauan Pustaka}

Frans Magnis Suseno dalam Etika Jawa mendeskripsikan kerukunan berasal dari kata "rukun" yang berarti keadaan selaras, tenang dan tentram, tanpa perselisihan dan pertentangan demi satu tujuan yakni kesatuan (Suseno, 2001). Dengan demikian, kerukunan sosial menciptakan kehidupan yang selaras, tentram dan tanpa perselisihan, tanpa konflik dalam bersatu menciptakan kehidupan yang damai dan sejahtera.

Kerukunan merupakan kondisi dan proses tercipta dan terpeliharanya pola-pola interaksi yang beragam di antara unit-unit yang otonom. Dalam arti bahwa kerukunan atau harmoni mencerminkan hubungan timbal balik yang ditandai oleh sikap saling menerima, saling mempercayai, saling menghormati dan menghargai, serta sikap saling memaknai kebersamaan. Kerukunan dapat menjadi katup pengaman (safety valve) bagi dis-integrasi sosial. Kerukunan dapat mereduksi konflik dan juga dapat membangun keseimbangan masyarakat (Ahmad, 2011). 


\section{METODE PENELITIAN}

Penelitian ini merupakan penelitian deskriptif kualitatif dengan tujuan menemukan dan menggambarkan kerukunanan sosial komunitas beda agama di permukiman transmigrasi desa Karave Mamuju Utara, terutama mengenai komunitas beda agama. Penelitian ini adalah penelitian deskriptif kualitatif dengan menggunakan analisis berdasarkan fakta dan realita-kenyataan di lapangan atau biasa dikenal dengan sebutan field research.

Dalam arti, suatu penelitian yang memberikan gambaran tentang kondisi secara faktual dan sistematis mengenai faktor-faktor, sifat-sifat serta hubungan antara fenomena yang dimiliki untuk melakukan akumulasi dasar-dasarnya saja, maka dari itu penelitian kualitatif dilaksanakan dengan cara mengeksplorasi dan memperkuat prediksi terhadap suatu gejala yang berlaku atas dasar data yang diperoleh di lapangan. (Sukardi, 2007).

Lokasi penelitian dipusatkan di desa Karave, Mamuju Utara. Karave masuk dalam bagian kecamatan Bulu Taba. Kecamatan Bulu Taba sendiri memiliki 7 (tujuh) desa, yakni desa Karave, desa Lilimori, desa Bukit Harapan, desa Ompi, desa Sumber Sari, desa Lelejea dan desa Kasta Buana. Kecamatan Bulu Taba sendiri mempunyai luas 432, 65 $\mathrm{Km} 2$ dengan jumlah penduduk 10.024 penduduk (BPS, 2013).

Karave memiliki luas $17,55 \mathrm{Km} 2$, mempunyai jarak $\pm 73 \mathrm{Km}$ dari ibukota kabupaten (Pasangkayu). Salah satu alasan peneliti memilih lokasi tersebut karena mempertimbangkan bahwa desa karave merupakan desa transmigrasi yang damai, tentram dan harmonis.

Pengumpulan data dilakukan dengan teknik wawancara, observasi dan dokumentasi (Creswell, 1994). Informan penelitian terdiri atas informan kunci yakni para tokoh agama. Informan ahli yakni akademi, pemimpin organisasi dan pakar sosial keagamaan. Informan biasa adalah masyarakat umum.

\section{PEMBAHASAN}

\section{Setting Lokasi Penelitian}

Desa Karave merupakan desa swadaya berupa daerah daratan yang mempunyai luas wilayah desa Karave yakni 17,55 Km2 dengan mempunyai 6 (enam) dusun, 19 RT (BPS, 2014). Adapun jumlah penduduknya 2.371 Jiwa yang terdiri dari 1.254 (Pria) dan 1.117 (Perempuan), dan pada tahun 2013 bertambah menjadi 2.497 jiwa dengan perincian 1.364 (Lk) dan 1.133 (Pr) dan 615 KK. Sedangkan pada tahun 2014 berkurang menjadi 2.442 yang terdiri dari $1.278(\mathrm{Lk})$ dan $1.164(\mathrm{Pr})$. Desa Karave mempunyai jarak ke ibukota kabupaten (Pasangkayu) $60 \mathrm{Km}$, sedangkan ke ibukota kecamatan 5, $5 \mathrm{Km}$.

Berdasarkan aspek etnis/suku yang mendiami desa Karave sebagai berikut: Jawa (656 orang atau 29,36\%), Toraja (577 orang atau $25,83 \%$ ), Bali (290 orang atau 12,98 \%), Bugis (270 orang atau 12,09\%), Kaili (201 orang atau 8,99\%), Makassar (124 orang atau $5,55 \%$ ), Mandar Mamuju (82 orang atau 3,67 $\%$ ), dan lainnya (34 orang atau 1,52\%). Selanjutnya pada aspek agama, di Desa Karave terdapat empat pemeluk agama resmi, yakni: Islam (1.904 orang), Kristen (569 orang), Katolik (364 orang) dan Hindu (207 orang). Para penganut agama hidup berdampingan dalam suasana solidaritas, kebersamaan, dan kedamaian. Belum pernah terjadi konflik yang mengatasnamakan agama bahkan setiap komunitas agama menyelenggarakan ibadah dengan damai (BPS, 2014).

\section{Faktor Pendukung Terjadinya Kerukunan Sosial di Desa Karave Kesadaran akan kebhinnekaan}

Sebuah desa yang mempunyai beragam etnis, suku, dan agama, tentu para penduduk sejak awal telah memiliki kesadaran keberagamaan yang menonjol. Dengan kondisi yang beragam dari segi etnis, suku dan agama di sebuah desa tersebut, maka telah timbul dari dalam dirinya sikap yang terbuka, inklusif dan bukan sikap yang semena-mena dan mendominasi dalam pergaulan sosial.

Dalam kehidupan sehari-hari, aktualisasi diri terhadap para pemeluk agama yang berbeda tidak dapat dielakkan begitu 
saja. Malahan, para penduduk tiap waktu melakukan interaksi sosial kapan dan di mana saja, baik itu di lapangan olah raga, pasar, maupun dalam kelompok usaha tani sawit. Interaksi dan pergaulan sosial antara umat beragama Islam, Protestan, Pantekosta, Advent, Katolik dan Hindu berlangsung setiap saat.

'Rasa kebhinnekaan dan keberagaman inilah, sehingga para warga di sini merasa nyaman dan tentram dan tidak ada perasaan mayoritas-minoritas yang mendominasi permukiman tersebut. dan para warga di sini saling menghargai dan menghormati di antara sesama warga' (Wawancara Pastor Kopong Boro Kosmas, Pastor Gereja Paroki Santo Yusuf Pekerja, Karave).

Kesadaran keberagaman merupakan piranti dalam mengenal satu individu dengan individu lainnya, pemeluk agama yang satu dengan pemeluk agama yang lainnya. Dengan adanya rasa kesadaran yang terpatri dalam dirinya, maka muncul dan dapat disaksikan di depan mata sikap tolong-menolong tanpa melihat dan memandang perbedaan suku, etnis dan agama. Bukankah setiap suku dan etnis mempunyai local knowledge berkaitan dengan sikap tolong-menolong dan bekerja sama. Begitu pula, dalam setiap agama terkandung banyak ajaran mengenai pentingnya antara satu individu dengan individu lainnya saling bahu-membahu dan tolong-menolong dalam tindakan yang positif.

Suku dan etnis yang berbeda, tidak menghalangi seseorang untuk melakukan kerja sama dan tolong-menolong jika diperlukan. Begitu pun, dengan agama yang berbeda bukanlah rintangan dalam melakukan perbuatan baik dengan sesama manusia.

'Walaupun mereka dari suku yang berbeda, agama berbeda, tetapi dalam berinteraksi, perbedaan itu ia simpan rapatrapat. Perbedaaan di antara kita, tak mengenal benci, buktinya kalau ada acara di dusun dan desa ini, kita sama-sama turun tangan dalam membantu' (Wawancara Pastor Kopong Boro Kosmas, Pastor Gereja Paroki Santo Yusuf Pekerja, Karave).

Penuturan ini memberi kesan kuat bahwa perbedaan suku/etnis dan agama tidaklah terlalu ditonjolkan dalam mewujudkan harmoni pada masyarakat heterogen, perbedaan tidak menjadikan tindakan kerja sama dan tolong-menolong terabaikan dalam praktek kehidupan sosial.

'Di sini itu, kita saling membantu. Contohnya kalau idul fitri, orang-orang nonmuslim itu berjaga-jaga. Begitu juga sebaliknya, kalau menjelang natal dan natal, gantian orang-orang muslim yang dapat giliran jaga, begitu seterusnya. Ini sudah berlangsung puluhan tahun. Nah itu yang bikin desa ini jarang ada konflik besar dalam masalah agama atau pertengkaran beda etnis dan suku' (Wawancara I Wayan Nugrata, Ketua Persatuan Hindu Dharma Indonesia Kec. Bulu Taba).

Pernyataan di atas mendeskripsikan bahwa komunitas beda agama saling membantu, karena ada rasa sadar bahwa sesama orang beragama mestinya saling membantu, saling menolong dan saling menghormati. Dengan adanya rasa sadar keberagaman inilah, sehingga harmoni semakin terajut dan menimalisasi konflik yang akan terjadi. Selain karena kebutuhan sosial, dalam ajaran agama apapun juga sangat dianjurkan untuk menghargai penganut agama lain. Salah satu tugas elit/tokoh agama adalah membangun bangunan kokoh spiritual para penganut agama yang sibuk dengan urusan duniawi. Para elit/tokoh agama di desa Karave mempunyai tanggung jawab sosial dalam menciptakan individu dan masyarakat yang sadar akan wilayah yang damai dan nyaman.

\section{Melakukan Perlombaan dan Pertandingan Agustusan}

Manusia sebagai makhluk sosial yang tiap hari bekerja untuk memenuhi kebutuhan keluarganya, di samping itu manusia juga membutuhkan refreshing atau pelepasan ketegangan, tekanan, stres dan depresi sosial serta menyegarkan fisik dan otak. Melakukan penyegaran fisik berupa olah raga di pagi dan sore hari merupakan salah satu hal yang dapat dilakukan. Begitu pula diadakannya perlombaan dan pertandingan olah raga antar kelompok maupun antar dusun mmberikan efek positif persahabatan dan persaudaraan di desa Karave. Hal ini diungkapkan oleh $\mathrm{H}$. Siswanto, sebagai berikut: 
'Setiap bulan agustus datang, para anak muda di desa ini membuat perlombaan antar kelompok, pertandingan sepak bola, bola volly, sepak takraw hingga untuk perlombaan lari kelereng dan lomba karung untuk anakanak. Para anak muda berbaur satu sama lain, tak mengenal etnis dan suku, apalagi agama. Begitu pula dengan anak-anak yang berbaur bersatu dalam keceriahan lari kelereng, makan kerupuk dan lomba karung. Perlombaan memberikan rasa persahabatan dan persaudaraan antar masyarakat Karave semakin erat' (Wawancara, Siswanto, Kepala Desa Karave).

Pemaparan kepala desa Karave sebagai pembina dalam perlombaan dan pertandingan agustus menunjukkan bahwa kegiatan tersebut memberikan peran positif dalam mempersaudarakan masyarakat Karave. Dengan adanya beberapa perlombaan yang diadakan tiap tahun memberikan warna tersendiri bagi masyarakat Karave. Kegiatan yang digilir dari dusun ke dusun tiap tahunnya menjadikan para aparatur dan pemuka dusun bersiap untuk melakukan event pertahunnya. Dalam kegiatan tersebut, peran pemuda tidak bisa dinafikan begitu saja, tetapi merekalah yang menjadi motor penggerak dari kegiatan tersebut. Para pemuda dan pemudilah yang membuat, menyusun dan mengatur kelancaran event agustusan tersebut. Di samping itu, tidak bisa dinafikan, peserta yang ikut perlombaan dan pertandingan agustusan mayoritas para pemuda dan remaja.

Perlombaan dan pertandingan di bulan agustus sangat membantu dalam menciptakan kerukunan antar umat beragama di kalangan para pemuda dan remaja di desa Karave. Bukankah para pemuda yang mempunyai "hati yang cepat panas" dibandingkan dengan hati orang tua. Oleh karena itu, jika gejolak jiwa para pemuda/remaja dapat "didinginkan" melalui kegiatan-kegiatan positif dan produktif. Jiwa yang bergolak yang semakin cepat tersulut jika tidak mempunyai wadah dalam "mendinginkannya".

Oleh karena itu, membuat atau melakukan kegiatan positif dapat mengarahkan para pemuda ke arah yang lebih baik. Merupakan hal yang sangat penting, siapa pun, bagi orang tua tidak mau melihat anak dan generasi pelanjutnya menjadi orang tidak berguna. Para orang tua, di mana dan kapan pun, ingin melihat dan memiliki generasi penerus yang tidak hanya menghabiskan waktu di tempat sabung ayam dan di depan botol minuman keras. Oleh karena itu, melakukan kegiatan positif yang sarat akan integritas, kreativitas dan prestasi sangat dibutuhkan bagi perkembangan pembangunan desa. Partisipasi para pemuda/remaja dalam membina kerukunan umat beragama di kalangan pemuda tidak bisa dinafikan begitu saja. Dengan adanya kegiatan ini membuat para pemuda/remaja menjalin persahabatan antar agama semakin erat dan akrab. Hal ini diungkapkan oleh Muhammad Mursyid:

'Di desa ini, setiap bulan agustus diadakan perlombaan sebagai bagian dari menyemarakkan HUT NKRI. Di tempat ini, pemudanya cukup aktif untuk membuat kegiatan, tanpa membeda-bedakan dari etnis, suku dan agamanya. Para pemuda dari pelbagai agama saling bergandeng tangan dalam menyukseskan kegiatan agustusan. Hal ini juga sering kami lakukan di asrama mahasiswa Mamuju Utara di Makassar. Di asrama, para penghuninya ada agama Islam, Protestan, Katolik dan Hindu, mereka saling bantu-membantu tanpa ada yang dibedakan“ (Wawancara Muhammad Mursyid, Ketua BKPRMI Mamuju Utara).

Muhammad Mursyid memaparkan bahwa banyak manfaat yang didapatkan dari kegiatan HUT RI Indonesia di bulan Agustus, seperti diadakan perlombaan dan pertandingan antar kelompok, antar dusun bahkan antar desa. Kegiatan seperti ini sering juga dilakukan ketika menjadi ketua Himpunan Mahasiswa Mamuju Utara (HIPMA MATRA) di Makassar. Kegiatan ini memberikan efek positif dalam mengukuhkan kerukunan umat beragama, sebab dalam perlombaan dan pertandingan tersebut, tidak dikenal perbedaan etnis, suku dan agama. Semua etnis, suku dan agama terlibat dan berpartisipasi aktif agar supaya kegiatan ini lancar dan sukses.

Begitu pula di desa Karave, kegiatan yang dilakukan atas "perintah" aparat pemerintahan desa, tetapi tetap menggalang keterlibatan aktif para organisasi keagamaan 
pemuda dan organisasi pemuda desa. Hal ini bisa dilihat dari struktur panitia pelaksana yang tidak hanya didominasi oleh satu agama saja, melainkan semua agama diberikan porsi yang setara dalam melancarkan kegiatan tersebut. Hal ini dilakukan agar supaya tidak timbul rasa cemburu di kalangan pemuda yang berbeda agama. Jika terjadi rasa cemburu, maka akan menimbulkan benih-benih benci, tidak suka, dan tidak percaya terhadap panitia pelaksana, sehingga membuat kegiatan tersendat.

Adakalanya terjadi keributan dan pertengkaran bagi yang tidak puas atas keputusan wasit dalam pelaksanaan kegiatan perlombaan dan pertandingan, akan tetapi hal itu yang berlaku sebentar dan tidak lama. Hal ini bisa dilihat dari pertandingan sepak bola dan bola volly, ada pertengkaran yang mewarnai, yang bisa merembes ke pertengkaran geng para pemuda. Namun, hal ini cepat diatasi dan didamaikan sehingga cepat pula teratasi. Di sisi lain perlombaan, khususnya berkaitan lomba lari karung, tarik tambang, makan krupuk, memasukkan jarum ke botol, main bola pake daster, lari kelereng, kesemuanya ini bersifat "lucu-lucuan" yang diadakan untuk memberikan kegembiraan dan kemeriahan dalam merayakan HUT Republik Indonesia di Karave.

Perlombaan itu mengandung nilainilai yang bisa diimplementasikan dalam kehidupan sehari-hari, seperti nilai kejujuran, tanggung jawab dan sportivitas. Nilai-nilai ini dapat berguna dan dimanfaatkan dalam tata perilaku kehidupan sosial antar sesama warga masyarakat. Dengan nilai itu pulalah, para warga masyarakat, khususnya generasi pelanjut dalam berinteraksi sosial mengedepankan nilai kejujuran dan sportivitas, mau mengakui kesalahannya, jika melakukan kesalahan. Kegiatan yang biasanya mengambil waktu seminggu ini bisa dijadikan ajang silaturrahim antara pemuda dari dusun satu ke dusun lainnya. Dan tidak bisa dinafikan, dalam keriuhan dan keramaian, mempunyai cerita cinta dikalangan para pemuda dan pemudi yang bertemu. Cerita cinta ini berakhir di pelaminan.

Di samping itu, perlombaan sepak bola memakai daster wanita merupakan perlombaan yang sangat dinantikan karena kelucuan dan mengundang gelak tawa bagi yang menontonnya. Para pemain kesebelasan memakai daster wanita dalam pertandingan ini, sehingga mengundang keriuhan. Walhasil, para penonton yang multi etnik, multi suku dan multi agama bersama-sama dan berbaur dalam menyaksikan perlombaan tersebut. Interaksi dan komunikasi sosial pun tidak terelakkan antar warga masyarakat Karave.

Pada titik inilah ruang publik sangat diperlukan. Ruang publik merupakan sebuah ruang yang dapat mendukung kebutuhan manusia akan tempat berkumpul dan melakukan tindakan positif. Salah satu fungsi ruang publik yakni mempunyai fungsi sebagai sarana mengeluarkan tekanan dan stres dari dalam pikiran. Dalam sejarah perkembangan manusia, dulunya dalam masyarakat primitif, upacara adat merupakan ruang publik yang sarana melepas lelah, kepenatan sehabis masa berburu, yang setiap anggota masyarakat mendapatkan dan dapat menikmati hidangan daging yang didapatkannya. Oleh karena itu, perlombaan yang diadakan publik merupakan sarana melepas lelah dan kepenatan beraktivitas sehari-hari. Dengan demikian, kegiatan ini merupakan ekspresi luapan stres atau depresi sosial akibat kesibukan sehari-hari dalam mencari nafkah.

Oleh karena itu, ruang publik menjadi penting bagi suatu komunitas masyarakat, pelbagai pendapat menyatakan bahwa di perkotaan akibat keterbatasan ruang publik menyebabkan anak-anak mengekspresikan dirinya lewat "kenakalan" di jalan raya. Ruang publik sebagai ruang dalam mengekspresikan jiwa tidak boleh diabaikan begitu saja, melainkan harus dihadirkan di tengah masyarakat. Maka dari itu, sebagai daerah transmigrasi, desa Karave mempunyai ruang publik dan dipergunakan untuk kemaslahatan umat, yakni tempat didirikannya tempat ibadah, sekolah untuk generasi pelanjut, serta tempat bermain bagi yang membutuhkannya untuk olah raga, dan sebagainya. Dominicus mengungkapkan bahwa kegiatan para pemuda yang berlangsung di bulan Agustus dan dilakukan di lapangan utama desa Karave sebagai ruang publik merupakan kegiatan rutin tahunan dalam menjaga soliditas dan keutuhan masyarakat Karave. 
Hal senada dikatakan oleh $\mathrm{H}$. Andi Safaruddin, Guru Agama Madrasah Aliyah di Karave

'Di sini, agustusan sangat bernilai. Karena apa? Agustusan dapat menjadi media perekat. Karena warga di sini ikut memeriahkan perlombaan. Siapa pun dia, semua etnis, semua agama, semuanya bersatu mensukseskan lomba agustusan' (Wawancara, H. Andi Safaruddin, Guru Agama sekaligus Imam desa Karave).

Pernyataan ini memberikan gambaran bahwa perlombaan di bulan agustus daerah perkotaan sudah hampir punah, hanya di kantor-kantor pemerintahan yang masih melakukan hal tersebut. Akan tetapi di daerah pedesaan, hingga kini masih terawat mulai dari perlombaan internal dusun, hingga perlombaan dan pertandingan satu dusun dengan dusun lainnya. Tradisi ini sangat penting untuk dirawat agar hal-hal yang beku dalam pergaulan sosial etnis dan suku, menjadi cair lagi. Bukankah terjadinya konflik sosial, salah satunya adalah karena kurang dan terhambatnya komunikasi sosial sehingga yang terjadi miskomunikasi dan tidak ada saling-pengertian di antara masyarakat yang bertikai. Olehnya itu, merawat sesuatu yang memberikan manfaat dalam mengukuhkan soliditas dan solidaritas sosial warga Karave sangatlah penting.

Pernyataan yang dipaparkan oleh Ustas H. Andi Safaruddin memberikan penegasan bahwa pelaksanaan kegiatan lomba dan kegiatan positif dalam rangka merayakan HUT RI merupakan hal yang sangat baik. Oleh karena itu, kegiatan semacam ini sangat perlu untuk dilestarikan, sehingga dengan pelestarian ini, interaksi sosial para warga dapat terjaga lebih baik lagi. Kegiatan tiap tahun ini memberi ruang terhadap warga Karave untuk saling bertemu dan silaturahim di sela-sela kesibukan beraktivitas. Momentum ini tidak bisa dilewatkan begitu saja, sebab memberi arti dalam menciptakan harmoni sosial di tengah warga Karave. Kegiatan publik semacam ini dapat dijadikan sebagai "pertemuan akbar" bagi warga Karave, karena dapat menyaksikan langsung perlombaan dan pertandingan yang diadakan oleh panitia pelaksana desa.

\section{Memperkukuh Jejaring sosial dalam kelompok tani sawit.}

Desa Karave dikenal sebagai desa yang ditumbuhi oleh Kelapa Sawit. Dalam menjaga, merawat dan memetik kelapa sawit dibutuhkan tenaga yang besar. Oleh karena itu, para pekerja membuat kelompok-kelompok untuk memetik dan memanennya. Dalam kelompok-kelompok inilah perbedaan suku, etnis dan agama tidak terlalu ditonjolkan. Dalam satu kelompok yang terdiri dari 15 orang, di dalamnya terdapat pekerja yang mempunyai latar belakang agama yang berbeda, ada Islam, Protestan, Katolik dan Hindu.

Lahan perkebunan kelapa sawit merupakan sumber utama dan vital ekonomi warga Karave yang mempunyai pengaruh dalam kehidupan sehari-hari. Dalam mengelola lahan tersebut dibutuhkan kerjasama antar warga sebab mereka mempunyai beragam informasi mengenai tata kelola pertanian. Etnis Jawa dan Bali memiliki kultur pertanian yang cukup mumpuni, sebab di daerah asalnya para transmigran ini adalah petani, walaupun hanya mengelola lahan yang sempit. Hal ini berbeda dengan etnis asal Nusa Tenggara Timur (NTT) yang memiliki kultur alam semesta tandus dan gersang sehingg bekerja sebagai nelayan. Begitu pula dengan penduduk lokal yang kebanyakan bekerja sebagai petani, tetapi nihil dalam hal pengelolaan kelapa sawit.

Oleh karena itu, proses adaptasi warga transmigran dengan lahan pertaniannya mengalami kendala, sehingga membutuhkan kerjasama yang dimulai dari kerjasama antar tetangga, hingga kerjasama antar komunitas. Dinamika kerjasama terus bergulir seiring pola interaksi sosial warga transmigran tersebut. Maka dari itu, pelembagaan petani dalam sebuah wadah menjadi penting karena bagian dari memperkuat basis kepentingan petani ketika berhadapan dengan perusahaan dalam hal pembelian dan penjualan komoditi hasil garapan. Yang paling menonjol dalam hal pembuatan kelompok tani adalah kerjasama dalam pengelolaan, penanaman, pemetaan, 
pembersihan hingga panen juga dilakukan secara bersama-sama.

'Para warga di sini bekerja berkelompok untuk petik kelapa sawit. Kelompok biasanya terdiri 10-15 orang, orangnya campur-baur, ada suku Bugisnya, ada suku Torajanya, ada etnis Bali, biasanya juga ada etnis Jawa. Mereka kan semua punya agama yang berbeda-beda. Di sini saling bantu-membantu, kalau mereka bertengkar, bisa gawat, kita tidak bisa petik kelapa sawit' (Wawancara H. Siswanto).

Bekerjasama dalam kelompok tani sawit merupakan hal yang sangat penting agar dapat sukses dalam mengelola dan memetik kelapa sawit. Semangat kerjasama dalam kelompok tani juga memengaruhi kesadaran akan pentingnya hidup dengan saling tolongmenolong dan toleransi. Dengan saling bekerjasama perbedaan agama tidak menjadi penghalang. Dengan perbedaan agama dalam sebuah kelompok tersebut, maka interaksi sosialnya pun akan semakin intens. Interaksi sosial yang tinggi akan mengurangi dan meminimalisasi terjadinya konflik agama.

'Saya bersyukur pada Tuhan tergabung dalam kelompok tani yang kompak khususnya teman-teman dari Jawa dan Bali, walaupun beda etnis dan agama tidak menghalangi mereka membagi pengetahuan bertaninya kepada etnis atau agama lain. Saya harus mengakui bahwa teman-teman dari Jawa dan Bali memiliki semangat kerja yang tinggi, tekun dan terampil' (Wawancara Yambung, Petani desa Karave).

Interaksi sosial yang melahirkan kerjasama merupakan hal yang penting dalam membangun dan menjalin kehidupan keagamaan yang harmoni. Bekerja sama dalam kelompok tani merupakan hal yang tidak bisa ditawar dan menjadi kewajiban moral para anggota kelompok tani untuk saling tolongmenolong, baik dalam lingkungan pengelolaan hingga saling tolong-menolong dalam acara syukuran di rumah masing-masing. Dengan demikian, eksistensi kelompok tani tidak hanya sekedar menjadi organisasi dalam rangka mengakomodasi para anggotanya untuk mengukuhkan kerjasama dan tolongmenolong. Selain itu, peran kelompok tani kelapa sawit berkontribusi dalam terciptanya toleransi dan damai dalam kehidupan kerukunan umat beragama.

'Konflik agama? Di sini belum pernah ada, mudah-mudahan selamanya tidak akan pernah terjadi. Kalau terjadi konflik, bisa jadi terancam kelaparan. Kita menghidupi keluarga dengan cara menjadi karyawan perusahaan, ya bekerja itu mesti berkelompok. Kelompoknya terdiri dari beberapa suku, agamanya pun tidak cuma Islam. Tetapi ada, Protestan, Katolik dan Hindu, cuma Budha kayaknya tidak ada di sini. Di sini enaknya berkelompok dengan beda suku dan beda agama, kita sedikit-banyaknya tahu tentang agama dan cara hidupnya (Wawancara Pendeta Yakob, Pendeta Kristen Protestan Karave).

Dalam pemaparan kepada penulis, Pendeta Yakob ingin menegaskan bahwa di desa Karave ini dikenal sebagai desa yang dihuni oleh multi etnis dan multi agama, hingga dikenal sebagai desa damai, karena belum pernah terjadi konflik agama skala besar. Sebab sejak dulu, para tokoh masyarakat dan tokoh agama telah menanamkan nilai-nilai persatuan dalam mengembangkan dan memajukan desa tersebut. Pengaplikasian nilai-nilai persatuan terwadahi dalam persatuan kelompok tani sawit. Hal ini dapat disaksikan bagaimana kelompok tani sawit yang didalamnya terdapat multi etnis, multi suku dan multi agama "bersatu dalam rasa", menyingkirkan ego primordial dalam rangka peningkatan sosial-ekonomi keluarga. Walaupun telah diketahui dari pakar konflik bahwasanya salah satu akar konflik sosial yakni bersikap fanatisme terhadap agama, sehingga memengaruhi tindakan-tindakan terhadap pemeluk agama lain. Secara sederhana, dapat diketahui bahwa adanya kelompok tani sawit yang berlatar belakang multi etnis dan agama akan sedikit-banyaknya memberikan pengalaman dan pandangan bekerjasama dengan pemeluk agama lain mempunyai nilai positif.

Dalam masyarakat majemuk, menutup rapat ruang komunikasi, baik antar multi agama dan multi etnis sama halnya dengan menciptakan ruang yang rawan konflik. Oleh karena itu, masyarakat majemuk, seharusnya para warganya berafiliasi dengan pelbagai macam institusi sosial (croos cutting 
affiliations) mengimbanginya dengan loyalitas ganda (croos cutting loyalities), membuka ruang berdialog dan berdiskusi, jikalau tidak, maka yang tercipta suasana kaku dan rigid sehingga gampang disulut dan meletuplah konflik sosial yang berkepanjangan. Tanpa interaksi sosial yang terbuka dengan sendirinya akan tercipta "ruang" yang rawan konflik di daerah itu. Oleh karena itu, menjalin hubungan interaksi sosial yang kaku, akan terbangun dengan sendirinya integrasi sosial yang semu.

Bukankah integrasi sosial yang semu adalah ibarat ban motor yang punya bocor halus, masih dapat dipakai untuk berkendaraan, tetapi sedikit demi sedikit akan mengeluarkan udaranya sehingga membuat ban kempes. Begitu pula dengan integrasi sosial yang semu, dapat bertahan, tetapi dari waktu ke waktu akan keropos dan membuyarkan integrasi sosial tersebut. Apa yang terjadi? Integrasi sosial justru akan mengarah ke dis-integrasi yang akan memporak-porandakan jalinan persaudaraan di desa tersebut. Dengan demikian, dalam mengukuhkan integrasi sosial, saling peduli, saling menghargai, dan saling menghormati antar warga desa tanpa memandang bulu dari segi suku, etnis dan agama sangatlah urgen. Ke semuanya melebur dalam satu wadah dalam mewujudkan desa dambaan bersama. Hal ini juga diungkapkan oleh Tokoh Pemuda Bulu Taba, Andi Tahmid:

'Hidup bertetangga dengan beda agama, ada kebaikannya, tetapi ada juga resikonya. Kalau kita bertetangga dengan nonmuslim, kalau ada acara memanggil untuk makan, ya tapi biasanya saya sebagai muslim berpikir panjang. Walaupun saya tahu, pribadi saya bukanlah muslim yang benar, tetapi soal makan, ya takutlah. Akan tetapi, biasanya mengerti kalau kita ini agama Islam. Tapi kalau di kelompok kerja, harus bekerja sama. Di dalam Al-Qur'an dinyatakan tolongmenolonglah dalam kebaikan dan jangan tolong-menolong dalam kerusakan“ (Wawancara Andi Tahmid, Pemuda Bulu Taba).

Bukan hanya agama Islam saja yang mengajarkan kepada umatnya untuk saling tolong-menolong, tetapi agama lain juga serta tiap suku mengajarkan dan memberikan nasehat dalam mengarungi hidup dan kehidupan ini. Apatah lagi dalam pergaulan sosial, saling membantu dan menolong bagi orang yang membutuhkan.

Persatuan dalam kelompok tani sawit merupakan hasil interaksi sosial yang semakin tinggi di antara mereka, sebab jika interaksi sosial menurun maka tidak terbangun solidaritas dan soliditas sosial. Bukankah solidaritas dan soliditas sosial merupakan modal sosial yang sangat urgen di desa Karave. Modal sosial ini menjadi penopang dalam melanggengkan harmoni sosial di desa tersebut. Oleh karena itu, persatuan tidak bisa dipisahkan dalam menciptakan harmoni sosial. Persatuan menjadi penting dalam membangun dan memajukan desa tersebut.

Salah satu yang mesti dilihat di desa ini adalah persatuannya, baik dalam kerja bakti, membantu seseorang atau lain sebagainya. Tak mengenal etnis, suku, apalagi agama. Para warga saling tolong-menolong dan bersatu dalam rangka pembangunan desa. Dalam hal bekerja sangat dibutuhkan persatuan. Bisa dilihat di kelompok tani sawit, para pekerja membutuhkan persatuan untuk petik sawit. Rasa persatuan ini yang terus bertahan dalam kehidupan sehari-hari, sehingga mereka saling akrab satu sama lainnya' (Wawancara Pendeta Yakob, Pendeta Kristen Protestan Karave).

Dalam konteks mikro, realita interaksi sosial di desa Karave semakin meningkat yang awalnya terlihat sikap curiga, apriori dan segan setelah proses adaptasi semakin intens, maka proses interaksi sosial semakin dinamis. Wujud interaksi sosial antar warga Karave menjangkau hingga ke sendi rumah tangga seperti acara pesta perkawinan, syukuran dan hari raya. Ketika salah satu warga menyelenggarakan suatu acara, mengundang tetangga dan kolega merupakan kewajiban moral walaupun dalam persoalan makanan mengalami kendala, tetapi dengan segera dapat teratasi. Yakni ketika warga non-muslim menyelenggarakan acara, maka mengundang ibu-ibu muslim memasak dan menggunakan peralatan mereka. 


\section{PENUTUP}

Berdasarkan rumusan masalah, uraian dan pembahasan yang telah dikemukakan sebelumnya dapatlah dikemukakan kesimpulan bahwa masyarakat desa Karave merupakan masyarakat transmigran yang berasal dari Nusa Tenggara Timur (Ende, Flores, Rote dan Kupang), Jawa Barat (Indramayu, Bandung, Ciamis dan Cianjur), Jawa Timur (Mojokerto, Bondowoso, Lamongan, Gresik dan Magetan), Jawa Tengah (Brebes, Majalengka, Sragen dan Kudus), Tana Toraja, Bali (Buleleng dan Karang Asem). Masyarakat transmigran yang terdiri dari 450 KK dipekerjakan untuk menggarap lahan $900 \mathrm{Ha}$ dengan perhitungan satu kepala keluarga mendapat 1 kapling (2 $\mathrm{Ha})$.

Untuk mendatangkan para warga transmigran dilakukan dengan 8 kali pendaratan, 5 kali pendaratan oleh transmigran inti dengan setiap pendaratan sebanyak $60 \mathrm{KK}$ dan 3 kali pendaratan oleh transmigran sisipan dengan setiap pendaratan sebanyak $50 \mathrm{KK}$. Dalam masyarakat transmigran ini, mempunyai corak etnis, suku dan agama yang berbeda, ada yang beragama Islam, Kristen, Katolik dan Hindu, mereka hidup bersama dalam satu-kesatuan wilayah yang saling berkomunikasi dan berinteraksi antara satu individu dengan individu lainnya.

Oleh karena itu, ada faktor pendukung tercipta dan terbangunnya kerukunan sosial, diantaranya: 1). Kesadaran akan kebinekaan. 2). Melakukan perlombaan dan pertandingan agustusan serta kegiatan positif lainnya dalam rangka mempererat jalinan silaturahmi. (3). Memperkukuh jejaring sosial dalam kelompok tani sawit.

\section{UCAPAN TERIMA KASIH}

Terlaksananya penelitian ini tidak bias dilepaskan dari dukungan berbagai pihak. Penulis sampaikan terima kasih kepada pemerintah, tokoh agama, tokoh desa, tokoh pemuda dan masyarakat desa Karave, Mamuju Utara beserta Badan Pusat Statistik Kab. Mamuju Utara atas dukungannya dalam memeroleh data primer dan sekunder untuk penelitian ini. Selanjutnya disampaikan terima kasih atas saran dan masukan yang diberikan oleh tim redaksi Jurnal Al-Qalam sampai pemuatan tulisan ini.

\section{DAFTAR PUSTAKA}

Ahmad, Haidlor Ali. 2011. Potret Kerukunan Umat Beragama Di Provinsi Jawa Timur. Jakarta: Puslitbang Kehidupan Keagamaan Kementerian Agama.

BPS. 2013. Mamuju Utara Dalam Angka. Mamuju Utara: Badan Pusat Statistik.

BPS. 2014. Badan Pusat Statistik Kec. Bulutaba. Mamuju Utara: Badan Pusat Statistik.

Creswell, John W. 1994. "Research design:Qualitative, Quantitative \& Mixed Methods Approaches." In Research Design:, , 1-26.

Darwis, M. 2007. Harmoni Dan Disharmoni Sosial Etnis Di Perkotaan (Studi Pola Interaksi Sosial Etnik Keturunan Tionghoa Dengan Etnik Makassar Di Kota Makassar). Disertasi Universitas Hasanuddin.

Halili. 2012. Kepemimpinan Tanpa Prakarsa: Kondisi Kebebasan Beragama/Berkeyakinan Di Indonesia 2012. Jakarta: Pustaka Masyarakat Setara.

Hasani, Ismail. 2012. Negara Menyangkal: Kondisi Kebebasan Beragama/Berkeyakinan Di Indonesia 2010. Jakarta: Pustaka Masyarakat Setara.

Misrawi, Zuhairi. 2009. Modul Pelatihan Membangun Toleransi. Jakarta: Moderate Muslim Society dan European Union.

Naipospos, Bonar Tigor. 2011. Politik Diskriminasi Rezim Susilo Bambang Yudhoyono: Kondisi Kebebasan Beragama/Berkeyakinan Di Indonesia 2011. Jakarta: Pustaka Masyarakat Setara.

Nuriyanto, Lilam Kadarin. 2018. Modal Sosial Dalam Membingkai Kerukunan Umat Beragama Di Surakarta. Jurnal AlQalam Balai Litbang Agama Makassar, 2018. 
Parekh, Bikhu. 2008. Rethinking Multiculturalism, Bambang Kukuh Adi (terj.). Jakarta: Kanisius dan IMPULSE.

Rahman, Budhy Munawar. 2010. Argumen Islam Untuk Pluralisme. Jakarta: Grasindo.

Raihani. 2010. Islam dan Kemajemukan: Studi Kasus Pesantren dan Pendidikan Multikultural, dipresentasikan di forum Annual Conference on Islamic Studies X, Banjarmasin 1-4 November 2010.

Shihab, Alwi. 1991. Islam Inklusif: Menuju Sikap Terbuka dalam Beragama. Jakarta: Mizan.

Siradj, Said Aqiel. 1999. Islam Kebangsaan: Fiqh Demokratik Kaum Santri. Jakarta: Pustaka Ciganjur.

Syatibi, Imam. 2008. Amuk Massa Berbasis Agama: Studi Kasus Pembakaran Wihara di Desa Jogomulyo Jawa Tengah, dalam Irwan Abdullah dkk (ed.) Dialektika Teks Suci Agama: Akulturasi Makna Agama dalam Kehidupan Masyarakat. Yogyakarta: Sekolah Pascasarjana UGM dan Pustaka Pelajar.

Sukardi. 2007. Metodologi Penelitian Kompetensi Dan Prakteknya. Jakarta: Gramedia Utama.

Suseno, Frans Magnis. 2001. Etika Jawa: Sebuah Analisa Filsafati Tentang Kebijaksanaan Hidup Jawa. Jakarta: PT. Gramedia Utama.

Tina N. K, Dwia Aries. 2005. Kekerasan Komunal dan Damai: Studi Dinamika dan Pengelolaan Konflik Sosial Luwu. Disertasi Universitas Hasanuddin.

Thomas, Art Semuel. 2018. Penggunaan Saluran Komunikasi Dalam Menjaga Sikap Hidup Toleransi Beragama Di Desa Kema Satu Kabupaten Minahasa Utara dalam Jurnal Al-Qalam Balai Litbang Agama Makassar, 2018.

Walzer, Michael. 1997. On Toleration. New Haven and London: Yale University Press.

Yaqin, Muhammad Ainul. 2005. Pendidikan Multikultural. Cross-Cultural Understanding untuk Demokrasi dan Keadilan. Cet. I; Yogyakarta: Nuansa Aksara. 
